\title{
Chapter 18 \\ Two Decades of Realistic Mathematics Education in Indonesia
}

\author{
Zulkardi Zulkardi, Ratu Ilma Indra Putri and Aryadi Wijaya
}

\begin{abstract}
In this chapter, we report on the process of adapting Realistic Mathematics Education (RME), a didactic approach founded by Freudenthal in the Netherlands, to the Indonesian context. In Indonesia, RME is called 'Pendidikan Matematika Realistik Indonesia' (PMRI). The chapter starts with describing how RME came to Indonesia. It was Sembiring from the Institut Teknologi Bandung who saw Jan de Lange, the director of the Freudenthal Institute of Utrecht University, presenting a keynote at the ICMI conference in Shanghai in 1994. Then the story continues with the decision of the Indonesian government to send six doctoral candidates to the Netherlands to learn about RME. The chapter also explains the process and results from the development and implementation of RME through a Dutch-Indonesian project Dissemination of PMRI (Do-PMRI). Moreover, the chapter describes examples of implementation strategies such as developing a master's program on RME, designing learning materials using RME theory and the development of a national contest of mathematical literacy using context-based mathematics tasks similar to those employed in the PISA test. The chapter ends with a discussion of two new initiatives at Sriwijaya University in Palembang, namely the development of a Centre of Excellence of PMRI and the establishment of a doctoral programme on PMRI.
\end{abstract}

Keywords Didactic $\cdot$ Realistic mathematics education $\cdot$ PMRI (Pendidikan Matematika Realistik Indonesia) • Impome (International Master's Programme on Mathematics Education) · PISA · Mathematical literacy • Context-based mathematics tasks

Z. Zulkardi $(\bowtie) \cdot$ R. I. I. Putri

Sriwijaya University, Palembang, Indonesia

e-mail: zulkardi@unsri.ac.id

R. I. I. Putri

e-mail: ratu.ilma@yahoo.com

A. Wijaya

Yogyakarta State University, Yogyakarta, Indonesia

e-mail: a.wijaya@uny.ac.id 


\subsection{Mathematics Reform Using Realistic Mathematics Education in Indonesia}

Learning from the successes in the United States and South Africa in reforming mathematics using Realistic Mathematics Education (RME), Indonesia also used and adapted RME to improve mathematics education. RME is a didactic approach or a domain-specific instruction theory for mathematics founded in the Netherlands (Van den Heuvel-Panhuizen, 2003; Van den Heuvel-Panhuizen \& Drijvers, 2014). In the Indonesian context, it is called 'Pendidikan Matematika Realistik Indonesia' (PMRI). The head of the PMRI team is Professor Sembiring, a mathematician from the Institut Teknologi Bandung. From 2001 to 2010 he managed the movement of PMRI through two projects supported by the Netherlands: the project Netherlands Programme for the Institutional Strengthening of Post-Secondary Education and Training Capacity (NPT) and the project Dissemination of Pendidikan Matematika Realistik Indonesia (Do-PMRI). Reports about the development and implementation of PMRI during these projects can be found in a journal article written by Sembiring, Hadi, and Dolk (2008) and in a book titled A Decade of PMRI in Indonesia written by Sembiring, Hoogland, and Dolk (2010a). In this book, all activities can be found that have taken place during ten years of PMRI in which PMRI has been disseminated in about 20 out of the 33 provinces in Indonesia.

Currently, five years after the Do-PMRI Project finished, one can question the sustainability of PMRI. Further publications about PMRI are rare. Also, the National Centre of PMRI that was set up in Bandung formally ended when the Department of National Education was split into two departments from 2015 on, one for compulsory education and one for higher education. Many questions about the continuation of PMRI are coming up. Is PMRI still alive in mathematics education in Indonesia? And if yes, what are the activities or developments of PMRI currently?

All three authors know a lot about RME or PMRI. They all have a doctorate either related to RME or to PMRI. The first author learned RME in the Netherlands and was the first person who got a doctoral degree on RME. Moreover, he was involved in the PMRI team from 1998. The second author learned about PMRI while the project was running in Indonesia and got a doctoral degree based on her dissertation about PMRI. The last author learned about RME at Utrecht University, first during his master's study and later during his doctoral study of which he graduated in 2015 . All our experiences with RME and PMRI, and our efforts to develop and implement PMRI have coloured this chapter.

The purpose of this chapter is to report the untold story of PMRI from the initiation of the adaptation process of RME into PMRI in Indonesia. This story covers a long period of time from the ICMI (International Commission on Mathematical Instruction) conference Shanghai 1994 to ICME (International Congress of Mathematical Education) Hamburg 2016, and is divided in three phases. The first phase focusses on the initiation of PMRI. The second phase describes the implementation and dissemination of PMRI, while the last phase focusses on how to sustain PMRI as an innovation after the project is over. In the following sections, these three phases 
will be presented and discussed. Hereafter, we will summarise the main merits and yields of PMRI.

\subsection{The Development of PMRI}

PMRI has been developed based on a joint Indonesian-Dutch project and its development can be divided in three time periods: (1) before the PMRI project (1994-2000); (2) during the PMRI project (2001-2010); and (3) after the PMRI project (20112015).

\subsubsection{Before the PMRI Project (1994-2000): Initiation Phase}

In 1994, it was Professor Sembiring from the Institut Teknologi Bandung who saw Professor Jan de Lange, the director of the Freudenthal Institute of Utrecht University presenting a keynote about RME at the ICMI conference in Shanghai. Sembiring, who represented the government of Indonesia, told Jan de Lange that Indonesia needed to reform school mathematics by changing the approach to teaching and learning school mathematics that was influenced by New Math. De Lange's presentation inspired Sembiring, and he asked De Lange to persuade the government that RME is the right approach to reforming mathematics education. Four years later, Jan de Lange agreed to help with the change, and he came to Indonesia twice, in 1998 and 2000 .

In 1998, the story continued with the decision of the Indonesian government to send six doctoral candidates to the Netherlands to learn about RME. Professor Jan de Lange and Professor Tjeerd Plomp (from the University of Twente) selected six teacher educators out of about twenty applicants from teacher education institutions all over Indonesia. These doctoral candidates were Ahmad Fauzan, Dian Armanto, Ipung Yuwono, Sutarto Hadi, Turmudi and Zulkardi. As students, they learned new knowledge and skills in the area of education and RME at the University of Twente in collaboration with Utrecht University. They went to Enschede and started the 'sandwich PhD programme' of the University of Twente and Utrecht University. The programme took four years and the research was conducted in Indonesian schools. In 2002, four of the participants received a $\mathrm{PhD}$ in mathematics education. Others received PhDs in Australia and Indonesia and also became leaders in the field. Now, all of these candidates are professors in RME and are the backbone of the continuation of PMRI.

In 2000, Jan de Lange was a keynote speaker at the Tenth National Conference on Mathematics at the Institut Teknologi Bandung. He informed the participants about two important concepts, namely RME and its success in the United States and 
in the Programme for International Student Assessment (PISA). That year, the first PISA international test was administered. As the head of the PISA Expert Group on Mathematics, he showed that PISA and RME have a strong relationship with respect to the use of context and the competences that were tested. When a participant asked him what the proof is that RME is a real solution to mathematics education in Indonesia, his argumentation was clear and simple. He mentioned that after the use of RME in a particular state in the United States, the average mathematics score in this state increased significantly. Also at this conference, one of his doctoral students, Zulkardi, presented his dissertation research in a panel session. It was on how to support student teachers both by a face-to-face course and a website about RME as an innovation in mathematics education in Indonesia (Zulkardi, 2002; Zulkardi, Nieveen, Van den Akker, \& De Lange, 2002a).

\subsubsection{During the PMRI Project (2001-2010): Implementation and Dissemination Phase}

The first project of PMRI was the NPT project (Netherlands Programme for the Institutional Strengthening of Post-Secondary Education and Training Capacity). It was funded by the Indonesian Directorate General of Higher Education (DIKTI) and supported by the Dutch Organisation for International Co-operation in Higher Education (Nuffic). The NPT project started in 2001 and ended in 2003. The first experiment of RME was at twelve primary schools with pre-service teacher education institutions at four universities. The four universities were Universitas Negeri Surabaya (UNESA) in Surabaya, Universitas Pendidikan Indonesia (UPI) in Bandung, Universitas Sanata Dharma (USD) in Yogyakarta, and Universitas Negeri Yogyakarta (Yogyakarta State University, UNY) also in Yogyakarta. Eight schools were managed by the Ministry of National Education, while four of the primary schools fell under the responsibility of the Ministry of Religious Affairs. All schools participated voluntarily. Each teacher education institution worked in close collaboration with three primary schools and became the coordinator and local centre of the reform in its region. In 2001, four of the doctoral students did research in Bandung, Yogyakarta and Surabaya. They played a significant role in helping the process of the PMRI experiment.

The second project is the Do-PMRI project (2006-2010). This project was also a joint project of Indonesia and the Netherlands. In Indonesia, DIKTI participated, and in the Netherlands, Algemeen Pedagogisch Studiecentrum (APS, national centre for school improvement) and FI. The managers of the project were Kees Hoogland, Maarten Dolk, and Sembiring. The primary development activities of this project were summarised as follows (Sembiring, Hadi, Zulkardi, \& Hoogland, 2010b):

- Development of PMRI learning materials such as exemplary lesson materials as well as textbooks for primary school level, including student books and teacher guides. At the end of the project, the textbooks for Grade 1-3 were published and used in primary schools all over Indonesia. 
- Developing a professional development programme or workshops on PMRI. There were two types of workshops, namely a start-up workshop and an implementation workshop. The participants were from primary schools and teacher education institutions. The implementation workshop was followed only by teachers and teacher educators who had implemented PMRI in their schools. In total, teachers and teacher educators from about twelve teacher education institutions were involved. The trainers of the workshop were about ten experts from FI and APS.

- Establishing the Bulletin PMRI for disseminating PMRI to student teachers, teachers, teacher educators and society. This newsletter consisted of implementation activities from all over Indonesia, such as experiences of teachers using PMRI in teaching, lesson plans and mathematics problems and it was published three times a year. Each volume was printed and disseminated by the project to PMRI schools and teacher education in all provinces in Indonesia.

- Developing centres for the development and research of PMRI, called Pusat Pengembangan dan Penelitian PMRI (P4MRI). Such centres were a place for PMRI teams to develop and do research on PMRI and were also a meeting point for teacher educators and school teachers doing activities on PMRI.

- Establishing a task force on design research. Within this task force, the guiding teacher educators and teachers in the project designed lesson materials using the PMRI approach, tried it out in classrooms and analysed their findings. Through this activity teacher educators could gain experience in doing design research by doing it themselves, which helped them in supervising their student teachers when they did design research in the final year.

- Initiation of the two-year master programme on RME at the FI. The programme was called IMPoME (International Master's Programme on Mathematics Education). This programme was followed by seven students and one of them was Aryadi Wijaya, the third author of this chapter. They went to Utrecht and were entirely funded by the Do-PMRI project and graduated in 2008.

In all activities above, the content and the didactics were based on PMRI. The overall goal of these activities was to improve the learning results in mathematics of students of primary school age in Indonesia. The learning of mathematics must be an inspiring and meaningful activity for all students, must be taught at each student's level, and must bring about that all students acquire a practical knowledge base that will help them to cope with quantitative situations in the world around them. Based on the results of the observations of the international advisory board of the PMRI project, the four-year project was a success. However, what worked in the selected pilot schools is not automatically implementable at a large scale. The international advisory board stated that the implementation and institutionalisation of PMRI in classrooms all over Indonesia was still an enormous endeavour. It can only be accomplished through the hard and enduring efforts of many: teachers, parents, principals, teacher educators, mathematicians, publishers, journalists, policy makers, politicians, and many more (Ekholm \& Van den Hoven, 2010). 


\subsubsection{After the PMRI Project (2011-2015): Dissemination Phase}

This phase elaborated on activities that were already developed and started within the PMRI project as well as activities that were initiated by the first author at the University of Sriwijaya (UNSRI) in Palembang. The activities are very important to make PMRI still alive as an innovation in Indonesian mathematics education.

\subsection{PMRI Growths Beyond the Project}

Over the years, PMRI resulted in a number of activities, programmes and events that were important for mathematics education in Indonesia. In the following sections we will subsequently discuss in more detail (1) the International Master's Program on Mathematics education (IMPoME); (2) the International Conference on Design Research (SEA-DR); (3) the Mathematical Literacy Contest (KLM) and the ContextBased Mathematics Tasks Indonesia (CoMTI) project; (4) the web portal on PMRI set up by the P4MRIs; (5) the Course on Realistic Mathematics Education for Junior Secondary School Mathematics Teachers in Southeast Asia (SEA-RME course), and (6) the Journal of Mathematics Education (JME).

\subsubsection{IMPoME}

The development of IMPoME was based on the master's programme that was designed by the Do-PMRI project. The success of this programme was proved by the graduation in 2007-2008 of seven master's students on the topic of RME. Then, in October 2008, a memorandum of understanding among the Sriwijaya University (UNSRI), the State University of Surabaya (UNESA) and Utrecht University was signed in Jakarta in the presense of DIKTI and Nuffic Neso Indonesia, which were responsible for the scholarships while the UNSRI and UNESA and Utrecht University were responsible for running the master's program. Also, a full curriculum was jointly developed. Good students were selected from candidates from all provinces in Indonesia, who then spent a year at UNSRI in Palembang or at UNESA in Surabaya, and a year in Utrecht.

One of the real outcomes of the Do-PMRI project was thinking about the future of PMRI in Indonesia which resulted in the design of IMPoME, the new master's programme on Realistic Mathematics Education. This legacy of PMRI was also acknowledged by the management of Nuffic, in the person of Kon Yap Tjay. According to him:

Important spin-offs of this project are a new master's degree programme along with a master's degree scholarship programme. The scholarship programme is funded by the Indonesian 
government, coupled with Nuffic-NESO Jakarta's funding of an international component for selected candidates. The new international master's degree programme in mathematics education is set up by universities in Surabaya and Palembang. (Yap, 2011, p. 90)

To begin with IMPoME, seven students were selected from all provinces in Indonesia. The selection team consisted of Maarten Dolk, Kees Hoogland, Sutarto Hadi and Zulkardi. The selection criteria were both knowledge about mathematics and mathematics education, proficiency in English, motivation to study hard and contribute, later when they would be back in Indonesia, to the dissemination of RME. The seven master's students were Ariyadi Wijaya, Al Jupri, Meliasari, Neni, Puspita, Roselyna, and Novi. All of them received their master's degree in 2009. Three of them also became a doctoral student. Ariyadi and Al Jupri got their doctorate from Utrecht University supervised by Professor Marja van den Heuvel-Panhuizen and Professor Paul Drijvers, and Roselyna graduated at the National Taiwan Normal University and was supervised by Professor Fou Lai Lin.

From 2009-2014, there was a total of 55 IMPoME students who learned about RME at Utrecht University. Their theses are published online by the FI and can be freely and fully downloaded at http://www.fisme.science.uu.nl/en/impome/.

In 2016, a new IMPoME is coming alive. This programme only involves a collaboration between UNSRI and Utrecht University. The scholarship will be supported by the Indonesian Endowment Fund for Education (LPDP), a part of the Financial Department of the Republic of Indonesia that manages the educational budget. The new programme uses the IMPoME model: students learn about RME in the Netherlands for one year, and in Indonesia for another year.

\subsubsection{International Conference on Design Research}

There are two things we learned and brought to Indonesia, namely RME and design research. All developments towards PMRI that have been conducted over the years used a design research method, which involved mostly starting with a preliminary study, then designing teaching material, followed by a teaching experiment and finally a retrospective analysis. The mathematical content and the didactics of the designs were based on RME. This design approach is one of the success strategies in disseminating PMRI in Indonesia.

For instance, IMPoME students had to write their theses using design research. They had to develop or design products such as lessons, assessment materials and learning media. All these were used as tools to support students learning mathematics using the PMRI approach. Two years after IMPoME started, students had to present their design and research results on PMRI in a local seminar either at UNSRI in Palembang or at UNESA in Surabaya.

In the third year, as a result of the collaboration between FI and UNSRI this seminar was extended into a national conference and an international conference for the Southeast Asian region on design research, called SEA-DR. Since 2013, this 
conference has taken place at UNSRI in Palembang. In 2016, the conference is held at Universitas Negeri Padang (UNP) in West Sumatera, Padang.

Some advantages of the SEA-DR conference are the following: (1) networking among researchers on PMRI; and (2) increasing the research and number of publications on PMRI in which design research is used. Up to now, each conference had about 400 researchers from all provinces in Indonesia and from Southeast Asian countries. In the future, this conference will move to other cities in- or outside Indonesia.

\subsubsection{Development of Mathematical Literacy in Indonesia}

Mathematical literacy has been a concern of the Indonesian government for years. In 2004, the Indonesian Ministry of National Education started implementing a competence-based curriculum, the Kurikulum Berbasis Kompetensi (KBK). In contrast to previous curricula that emphasised students' acquisition of knowledge, KBK focussed on developing students' ability to apply knowledge. Concerning mathematics education, KBK explicitly stated that mathematics education should target developing students' ability to: (1) understand the concepts of mathematics, explain the relevance of concepts, and apply the concepts or algorithms in a flexible way in problem solving; (2) solve problems that include being able to understand a problem, design and complete a mathematical model to solve it, and interpret the solution; and (3) appreciate the purpose of mathematics in life (Pusat Kurikulum, 2003). In the newly implemented curriculum of 2013, the Indonesian government also mandates that education must be relevant to the needs of life and should offer students opportunities to apply their knowledge in society. In line with these curricula, PMRI promotes mathematical literacy through the use of real-world problems in learning mathematics (Sembiring et al., 2008, 2010b).

Despite Indonesia's attention for mathematical literacy, the results of the PISA studies indicate Indonesian students' poor mathematical literacy. In the PISA 2012 study, for example, only $0.3 \%$ of Indonesian students were top performers in mathematical literacy who could solve mathematics problems requiring sophisticated mathematical modelling and well-developed reasoning skills (Organisation for Economic Cooperation and Development, OECD, 2013). In contrast, most Indonesian students, that is, $75.7 \%$ of students, did not reach Level 2, which is set as the baseline level of mathematical literacy. These students could only solve mathematics problems that use familiar contexts, have obvious questions, and present all relevant information. Furthermore, they were able to identify relevant information and carry out routine mathematical procedures only if explicit instructions were given. This poor performance of Indonesian students in PISA has prompted initiatives to improve students' mathematical literacy. In this chapter, we would like to report two attempts that have been carried out to improve Indonesian students' mathematical literacy, namely the Kontes Literasi Matematika (KLM, mathematical literacy contest) and the Context-Based Mathematics Tasks Indonesia (CoMTI) project. 


\subsubsection{Mathematical Literacy Contest}

The KLM is conducted for junior high school students, that is, around 14-15 years old students. The rationale of this contest is that improving students' mathematical literacy can be done by providing them with problems addressing the application of mathematics. It is expected that KLM may raise awareness of mathematical literacy. The participants in KLM have to deal with PISA-like problems. In the first round, the participants have to solve the problems in a written format. About $20 \%$ of participants who get the highest grade will continue to the second round of the contest. In this round, the participants have to solve problems and present their solutions and solving strategies orally. The three best performers in the second round of the contest were named as the champions (for more details, see Stacey et al., 2015).

The first KLM took place in 2010 and was initiated by Professor Zulkardi of Sriwijaya University, and was therefore only conducted in Palembang (South Sumatera). In 2011, KLM was held in seven cities in seven provinces, that is, Jakarta (Jakarta), Surabaya (East Java), Yogyakarta (Yogyakarta), Medan (North Sumatera), Palembang (South Sumatera), Makassar (South Sulawesi), and Banjarmasin (South Kalimantan). After 2011 the number of participating cities increased. In 2012, five new cities joined KLM to make a total of twelve participating cities. These five new cities were Kupang (East Nusa Tenggara), Malang (East Java), Padang (West Sumatera), Semarang (Central Java), and Singaraja (Bali). In 2015, eighteen cities in seventeen provinces participated in the contest. From the second KLM in 2011 on, the contest was conducted at two levels, that is, regional (towns or areas) and the national level, with the champion from every region competing to get the national champion. At the regional level, KLM is organised by the P4MRI in the participating city. At the national level, KLM is organised by the Institute for the Development of PMRI (Institut Pengembangan PMRI or IP PMRI). In the beginning, KLM was only held by IP PMRI and P4MRIs. However, later on, P4TK Matematika ${ }^{1}$ joined as an additional organising committee of the KLM at the national level. P4TK Matematika is a government institution under the Indonesian Ministry of Education. The involvement of P4TK Matematika in KLM indicates the government's support for developing Indonesian students' mathematical literacy.

\subsubsection{The Context-Based Mathematics Tasks Indonesia Project}

Another attempt to improve students' mathematical literacy is the Context-Based Mathematics Tasks Indonesia (CoMTI) project. CoMTI was a PhD project of Ariyadi Wijaya under the supervision of Professor Marja van den Heuvel-Panhuizen and Doctor Michiel Doorman at the Freudenthal Institute at Utrecht University. The similarity between KLM and the CoMTI project is the use of context-based tasks, that is, KLM uses PISA-like tasks and CoMTI used released PISA tasks. However,

\footnotetext{
${ }^{1}$ Pusat Pengembangan dan Pemberdayaan Pendidik dan Tenaga Kependidikan Matematika (Centre for the Development and Empowerment of Mathematics Teachers and Educational Personnel).
} 
unlike KLM that attempts to improve mathematical literacy by using PISA-like problems as springboards for raising awareness on mathematical literacy (Widjaja, 2011), the CoMTI project took a broader perspective. The CoMTI project focussed on three interrelated issues regarding mathematical literacy in Indonesia. The first issue was Indonesian students' difficulties in solving context-based tasks. Second, the reasons for students' difficulties were examined. Lastly, based on the first and second issue, it was studied how students' performance on context-based tasks, or on mathematical literacy, could be improved.

In relation to Indonesian students' difficulties in solving context-based tasks, Wijaya, Van den Heuvel-Panhuizen, Doorman, and Robitzsch (2014) performed an analysis of students' errors. The error analysis revealed that of the errors made by the students $38 \%$ were comprehension errors, $42 \%$ were transformation errors, $17 \%$ were mathematical processing errors, and $3 \%$ were encoding errors. These results indicate that when solving context-based tasks, Indonesian students mostly experienced difficulties in comprehending what the tasks are about and in transforming them into mathematical problems. These difficulties mean the students could not identify relevant mathematics concepts or procedures required to solve a contextbased task; which in fact is a key ability for mathematical literacy. To know possible reasons for students' difficulties in solving context-based tasks, the CoMTI project focussed on investigating opportunities received by students to learn to solve context-based tasks. For this purpose, two dimensions of opportunity-to-learn were considered: textbooks and teachers' teaching practices. A study by Wijaya, Van den Heuvel-Panhuizen, and Doorman (2015a) revealed that Indonesian mathematics textbooks do not provide enough opportunities for students to learn to solve contextbased tasks. After analysing three Indonesian mathematics textbooks, Wijaya et al. found that only $10 \%$ of the tasks in the textbooks were context-based tasks. Of these context-based tasks, only a quarter required mathematical modelling or asked students to identify the relevant mathematics concepts or procedures. It means that only $2.5 \%$ of the tasks in Indonesian mathematics textbooks were found to address mathematical literacy. Furthermore, of the context-based tasks in the textbooks, $85 \%$ of the tasks provided only the relevant information. It indicates that the complexity of context-based tasks found in Indonesian textbooks was mostly below PISA's baseline Level 2. The second dimension of opportunity-to-learn investigated in the CoMTI project was teachers' teaching practices. For this dimension Wijaya, Van den Heuvel-Panhuizen, and Doorman (2015b) found that the way teachers taught context-based tasks also did not provide sufficient opportunities for students to learn to solve context-based tasks. The teachers tended to use a directive teaching approach in which they tell the students what a context-based task is about, translate the task into a mathematical problem, and explain what mathematical procedure to carry out. In such teaching, students are not encouraged to carry actively out and reflect on the stages of solving context-based tasks. This directive teaching approach was mostly used in the comprehension and transformation stages of problem solving, which are crucial stages of mathematical literacy. After identifying Indonesian students' difficulties and their possible reasons, the CoMTI project focussed on designing a way to improve students' mathematical literacy. For this part of the study an intervention 
programme was developed comprising a consultative teaching approach and a set of context-based tasks with metacognitive prompts. An examination of the effect of the intervention on students' errors showed a positive influence of the opportunity-tolearn on reducing students' errors. Students who received the opportunity-to-learn could better understand the instruction for a context-based task and had improved performance in selecting relevant information (Wijaya, Van den Heuvel-Panhuizen, Doorman, \& Veldhuis, 2018).

The results of KLM and CoMTI show potential for improving Indonesian students' mathematical literacy. Of course, it should be highlighted that developing students' mathematical literacy is not the work of an individual person or organisation. Supports from the government such as P4TK Matematika's participation in KLM, and also the commitment of IP PMRI and P4MRIs are crucial to sustaining the programme for improving students' mathematical literacy. The CoMTI project was conducted in the Province of Yogyakarta. Therefore, it is important to incorporate the project into a programme of P4MRIs so that the data can be more representative for Indonesia in general. Furthermore, the investigation into possible reasons for Indonesian students' poor mathematical literacy emphasised only factors that are related to cognitive aspects: textbooks and teachers' teaching practices. However, as pointed out by Leron and Hazzan (1997), students' thinking is influenced not only by cognitive factors, but also by affective factors. Therefore, investigating emotional factors such as students' motivation might provide a comprehensive picture of possible factors that influence student performance.

\subsubsection{Development of a Web Portal on PMRI}

In about 22 provinces in Indonesia, the P4MRIs have set up their website or blog. The main goal of these blogs is to support users with information about PMRI and its development from each area. To connect and link all blogs from all over Indonesia, a P4MRI web portal was developed by Zulkardi in 2011; see http://p4mri.net/new/. This web portal functions as a clearinghouse for PMRI information, documentation for activities, and resources.

The P4MRI web portal contains:

- Content about PMRI such as examples of learning materials, teacher guides on PMRI, examples of student works and assessment problems.

- Resources on PMRI for teachers, student teachers and researchers such as papers, thesis, dissertations, images, applets, and videos.

- Links to all websites PMRI from all PMRI centres in Indonesia as well as from other countries.

- Other resources including the curriculum of the master's programme and the doctoral programme on RME, scholarships, conferences, PISA, mathematics contests and journals on mathematics education. 
With the recent growth in the number of internet users in Indonesia, the P4MRI web portal is a useful tool in for disseminating PMRI in a big country such as Indonesia.

\subsubsection{Course on Realistic Mathematics Education for Junior Secondary School Mathematics Teachers in Southeast Asia}

One of the interesting effects of PMRI in Indonesia is that it became the main content for the professional development programme, the Course on Realistic Mathematics Education for Junior Secondary School Mathematics Teachers in Southeast Asia or the SEA-RME course. The course is developed by the PMRI team, and was launched for the first time in October 2012. The goal of the course is enhancing junior secondary school mathematics teachers' competence in mathematics teaching and learning using RME.

The SEA-RME course contains the following modules: Introduction to RME, Indonesian Experience in Disseminating RME, Designing RME Lesson, Assessment, RME, PISA/TIMSS, Lesson Study, Classroom Observation and Teaching Practice in the School. These modules are delivered by several facilitators from some prominent universities in Indonesia (Sanata Dharma University, Sriwijaya University, Padang State University and Lambung Mangkurat University, Yogyakarta State University). An example of a 10-minute-video on introducing PMRI to training participants from ASEAN countries can be viewed at https://www.youtube.com/watch? $\mathrm{v}=\mathrm{fjXyNmNTBWg}$.

\subsubsection{A New International Journal on Mathematics Education}

In 2010 a new journal on mathematics education was initiated by Zulkardi, the vice president of the Indonesian Mathematical Society (IndoMS). The Indo-MS Journal on Mathematics Education (JME) was launched during the opening of the Fifteenth National Conference on Mathematics (KNM15) at the University of Manado, North Sulawesi, on July 31, 2010 by the President of IndoMS, Professor Widodo. JME, which is the first international journal on mathematics education in Indonesia, is devoted to school mathematics teachers, teacher educators, and university students who want to publish their research articles about mathematics education. Some of the contributors are also well-known researchers in mathematics education such as:

- Lee Peng Yee and Berinderjeet Kaur from Singapore

- Kaye Stacey and Tom Lowrie from Australia

- Koeno Gravemeijer, Frans van Galen and Dolly van Eerde from the Netherlands 
- Christa Kaune and Edyta Nowinska from Germany

- Fou Lai Lin from Taiwan.

After five years, in September 2015, this journal was successfully accredited by DIKTI and the Minister of Research, Technology, and Higher Education in Indonesia. This accreditation is an indication that the journal has been managed in a good and a consistent way. Surprisingly, up to Volume 7, released in January 2016, 47 (58\%) of the 81 published articles were about RME or PMRI. One might say that $J M E$ could also be called 'JRME' (Journal on Realistic Mathematics Education). On top of that, one can say that the increase in publications on RME shows the sustainability of research on RME in Indonesia. The journal has also been indexed in DOAJ, ERIC Database, and Google Scholar. All articles can be freely accessed at www.jims-b.org or http://ejournal.unsri.ac.id/index.php/jme.

\subsection{New Developments on PMRI}

In 2014 a small-scale joint research project on PMRI was started between UNSRI and Utrecht University. This research project was supported by the Rector and the Dean of UNSRI. The goal of this initiative is a way to sustain the academic relationship between the two universities. The two topics addressed in this project are sociomathematical norms in mathematics teaching in primary school, and mathematics and science literacy in teacher education. The main goal of the first topic is to support teachers in how to manage an interactive PMRI classroom (Putri, Dolk, \& Zulkardi, 2015) and the goal of the second topic is to develop a PISA centre in Indonesia and to improve the quality of mathematics and science education at the undergraduate level (Zulkardi, 2015).

In 2015, UNSRI and Utrecht University started a new IMPoME programme. The scholarship will be supported by LPDP-Lembaga Pengelola Dana Pendidikan, a department of the Ministry of Finances that is involved with the educational budget. As in the previous IMPoME programme, in the first semester students will take basic courses on RME at UNSRI. Then, they will take their main courses on RME at Utrecht University at the Freudenthal Institute for two semesters. In the fourth semester, they have to do research on RME in Palembang. Finally, they have to defend their thesis before graduating the programme and getting a M.Sc. degree.

A new doctoral programme on mathematics education, that uses the IMPoME model, has also been created. This means that first students will be recruited by a joint team from both universities. Students will then spend a year taking four courses and writing a good research proposal at UNSRI. In the second year, there will be two groups of doctoral students, namely one group who will continue at Utrecht University for three years and another group who will continue for two years at UNSRI and will take their doctorate there. 


\subsection{PMRI Continues}

Some questions about the untold stories about PMRI that were asked in the introduction have been answered in this chapter. For instance, what was the history of PMRI before, during and beyond the PMRI project? Some development and research activities about PMRI are still continuing and need to be supported.

There is also a new initiative on PMRI, namely developing a Centre of Excellence of PMRI at the University of Sriwijaya Palembang. It will have a role as a national centre of PMRI, and will manage all local centres of PMRI from all provinces in Indonesia.

At the end of this chapter, the story of PMRI from ICMI 1994 in Shanghai to ICME 2016 in Hamburg will stop, but activities related to PMRI are still continuing in Indonesia. These activities support stakeholders such as teachers, student teachers, learners, teacher educators, researchers, and book writers in reforming mathematics education in Indonesia and can be seen as proof that the movement of PMRI as an innovation in mathematics education sustains.

All these activities on PMRI have implications for policies on and further research in mathematics education in Indonesia. They inspire student teachers, teachers, and researchers for teaching mathematics. These activities need to be managed and supported by all parties to make it possible that in the coming decades, they will help and encourage many people to learn about PMRI in mathematics education in Indonesia.

Acknowledgements The authors wish to express their gratitude to the colleagues who brought their support in the preparation of this chapter, and in particular to the head of the PMRI team, R. K. Sembiring.

\section{References}

Ekholm, M., \& Van den Hoven, G. (2010). Summary of PMRI-Majulah! A report of the International Advisory Board of PMRI. In R. K. Sembiring, K. Hoogland, \& M. Dolk (Eds.), A decade of PMRI in Indonesia (p. 88). Jakarta, Indonesia/Utrecht, the Netherlands: APS International.

Leron, U., \& Hazzan, O. (1997). The world according to Johnny: A coping perspective in mathematics education. Educational Studies in Mathematics, 32(3), 265-292.

OECD. (2013). PISA 2012 results: What students know and can do. Student performance in mathematics, reading and science. Paris: OECD.

Pusat Kurikulum [National Curriculum Centre]. (2003). Kurikulum 2004. Standar kompetensi mata pelajaran matematika Sekolah Menengah Pertama dan Madrasah Tsanawiyah [The curriculum 2004: The competence standards for mathematics in Junior High School and Islamic Junior High School]. Jakarta, Indonesia: Departemen Pendidikan Nasional.

Putri, I. I. P., Dolk, M., \& Zulkardi, Z. (2015). Professional development of PMRI teachers for introducing social norms. Indonesian Mathematical Society Journal on Mathematics Education, 6(1), 11-19.

Sembiring, R. K., Hadi, S., \& Dolk, M. (2008). Reforming mathematics learning in Indonesian classrooms through RME. ZDM Mathematics Education, 40(6), 927-939. 
Sembiring, R. K., Hadi, S., Zulkardi, Z., \& Hoogland, K. (2010b). The future of PMRI. In R. K. Sembiring, K. Hoogland, \& M. Dolk (Eds.), A decade of PMRI in Indonesia (pp. 189-190). Utrecht, the Netherlands: APS International.

Sembiring, R. K., Hoogland, K., \& Dolk, M. (Eds.). (2010a). A decade of PMRI in Indonesia. Utrecht, the Netherlands: APS International.

Stacey, K., et al. (2015). PISA's influence on thought and action in mathematics education. In K. Stacey \& R. Turner (Eds.), Assessing mathematical literacy - The PISA experience (pp. 275-306). Cham, Switzerland: Springer International Publishing.

Van den Heuvel-Panhuizen, M. (2003). The didactical use of models in realistic mathematics education: An example from a longitudinal trajectory on percentage. Educational Studies in Mathematics, 54(1), 9-35.

Van den Heuvel-Panhuizen, M., \& Drijvers, P. (2014). Realistic Mathematics Education. In S. Lerman (Ed.), Encyclopedia of mathematics education (pp. 521-525). Dordrecht, the Netherlands: Springer. https://doi.org/10.1007/978-94-007-4978-8.

Widjaja, W. (2011). Towards mathematical literacy in the 21st century: Perspectives from Indonesia. Southeast Asian Mathematics Education Journal, 1(1), 75-84.

Wijaya, A., Van den Heuvel-Panhuizen, M., Doorman, M., \& Robitzsch, A. (2014). Difficulties in solving context-based PISA mathematics tasks: An analysis of students' errors. The Mathematics Enthusiast, 11(3), 541-554.

Wijaya, A., Van den Heuvel-Panhuizen, M., \& Doorman, M. (2015a). Opportunity-to-learn contextbased tasks provided by mathematics textbooks. Educational Studies in Mathematics, 89(1), $41-65$.

Wijaya, A., Van den Heuvel-Panhuizen, M., \& Doorman, M. (2015b). Teachers' teaching practices and beliefs regarding context-based tasks and their relation to students' difficulties in solving these tasks. Mathematics Education Research Journal, 27(4), 637-662.

Wijaya, A., Van den Heuvel-Panhuizen, M., Doorman, M., \& Veldhuis, M. (2018). Opportunityto-learn to solve context-based mathematics tasks and students' performance in solving these tasks - Lessons from Indonesia. EURASIA Journal of Mathematics, Science and Technology Education, 14(10), em1598; https://doi.org/10.29333/ejmste/93420.

Yap, K. T. (2011). Realistic Mathematics Education in a project approach. In R. K. Sembiring, K. Hoogland, \& M. Dolk (Eds.), (2010). A decade of PMRI in Indonesia. Utrecht, the Netherlands: APS International.

Zulkardi, Z. (2002). Developing a learning environment on realistic Mathematics Education for Indonesian Student Teachers. Published doctoral thesis of the University of Twente. Enschede, the Netherlands: PrintPartners Ipskamp. Available online at http://doc.utwente.n1/58718/1/thesis_ Zulkardi.pdf.

Zulkardi, Z. (2015). Using PMRI and PISA for improving research and learning on mathematics literacy of Indonesian students. Paper presented as Invited Speaker at the International Conference on Mathematics, Natural Sciences and Education (ICoMaNSed 2015), State University of Manado, 7-8 August 2015.

Zulkardi, Z., Nieveen, N., Van den Akker J., \& De Lange, J. (2002a). Implementing a 'European' approach to mathematics education in Indonesia. In Proceeding of Second International Conference on Teaching Mathematics. Crete, Greece, July 1-6, 2002. [Online]. Available at: http:// www.math.uoc.gr/ ictm2/Proceedings/pap81.pdf. 
Open Access This chapter is distributed under the terms of the Creative Commons Attribution 4.0 International License (http://creativecommons.org/licenses/by/4.0/), which permits use, duplication, adaptation, distribution and reproduction in any medium or format, as long as you give appropriate credit to the original author(s) and the source, a link is provided to the Creative Commons license and any changes made are indicated.

The images or other third party material in this chapter are included in the work's Creative Commons license, unless indicated otherwise in the credit line; if such material is not included in the work's Creative Commons license and the respective action is not permitted by statutory regulation, users will need to obtain permission from the license holder to duplicate, adapt or reproduce the material. 